Jurnal Keperawatan Silampari

Volume 4, Nomor 2, Juni 2021

e-ISSN: 2581-1975

p-ISSN: 2597-7482

DOI: https://doi.org/10.31539/jks.v4i2.1546

IDMEKDE

\title{
PENERAPAN CLINICAL PATHWAY S SEBAGAI INSTRUMEN PENGENDALIAN BIAYA PELAYANAN DI DR. SOETOMO: STUDI PENELITIAN TINDAKAN PENDERITA BPJS YANG MENJALANI OPERASI CAESAR DENGAN SISTEM PEMBAYARAN INA-CBG
}

\author{
Annisa Fitria ${ }^{1}$, Andri Sofa Armani ${ }^{2}$, Thinni Nurul Rochmah ${ }^{3}$, \\ Bangun Trapsila Purwaka ${ }^{4}$, Widodo Jatim Pudjirahardjo ${ }^{5}$ \\ Universitas Airlangga ${ }^{1,2,3,5}$ \\ Dr. Soetomo Hospital Surabaya ${ }^{4}$ \\ annisa.fitria-2018@fkm.unair.ac.id ${ }^{1}$
}

\begin{abstract}
ABSTRAK
Penelitian ini bertujuan untuk mengetahui pengaruh penggunaan clinical pathway sebagai alat pengendalian total biaya rumah sakit riil pasien BPJS yang menjalani operasi caesar. Metode yang digunakan dalam penelitian ini adalah action research. Hasil penelitian menunjukkan bahwa rata-rata biaya rumah sakit riil secara signifikan lebih tinggi setelah penerapan CP dengan $\mathrm{p}=0,019$. Rata-rata lama rawat, biaya pelayanan dan biaya rumah sakit nyata lebih rendah secara signifikan pada kelompok formulir CP lengkap dengan $\mathrm{p}=$ $0,012, p=0,013$ dan $p=0,012$. Simpulan, Penelitian ini menunjukkan bahwa penerapan clinical pathway dapat mengurangi lama rawat inap dan biaya rumah sakit yang sebenarnya pada pasien bedah caesar dan menunjukkan bahwa penggunaan clinical pathway dapat membuat layanan lebih efisien.
\end{abstract}

Kata Kunci: Biaya Rumah Sakit, Clinical pathway, Operasi Caesar

\begin{abstract}
This study aims to determine the effect of using clinical pathway s to control total actual hospital costs for BPJS patients who undergo a cesarean section. The method used in this research is action research. The results showed that the average actual hospital costs were significantly higher after the application of $C P$ with $p=0.019$. The average length of stay, service costs, and hospital costs were significantly lower in the entire CP form group with $p$ $=0.012, p=0.013$, and $p=0.012$. In conclusion, this study shows that the application of clinical pathway s can reduce the length of hospitalization and actual hospital costs for cesarean section patients and indicates that clinical pathway s can make services more efficient.
\end{abstract}

Keywords: Hospital Costs, Clinical pathway, Caesarean Section

\section{PENDAHULUAN}

Rumah sakit merupakan suatu organisasi atau institusi yang mempunyai ciri padat modal (capital intensive), padat teknologi (technology intensive), padat karya (labor intensive) dan padat keterampilan (skill intensive) dengan sumber daya manusia yang sangat beragam. Rumah sakit dituntut untuk dapat memberikan pelayanan yang memuaskan pelanggan. 
Kementerian Kesehatan RI Nomor: 1663/MENKES/SK/XII/2005 tentang Penerapan Sistem Diagnostic Related Group (DRG) mengembangkan suatu sistem berupa INA-DRG (Indonesian-Diagnosis Relating Group) yang disusun berdasarkan 15 rumah sakit vertikal, dengan ICD 10 untuk diagnosis dan ICD 9 CM untuk prosedur tindakan serta biaya berdasarkan tarif yang berlaku pada waktu tersebut. DRG merupakan suatu cara mengidentifikasi pasien yang mempunyai kebutuhan dan sumber yang sama di rumah sakit kemudian dikelompokkan ke dalam kelompok yang sama. DRG atau sistem pembiayaan kelompok diagnosa terkait adalah suatu sistem atau cara pembayaran kepadapenyelenggara pelayanan kesehatan untuk pelayanan yang diselenggarakannya tanpa memperhatikan jumlah tindakan atau pelayanan yang diberikan, melainkan pengelompokan pelayanan medis ke dalam suatu besaran pembiayaan menurut kelompok penyakit dimana pasien yang sedang ditangani tersebut berada.

Pola pembiayaan ini merupakan suatu kemajuan dalam ranah pembiayaan pelayanan kesehatan, tetapi perlu disadari bahwa sistem ini belum mencerminkan realitas kebutuhan pembiayaan di seluruh pelosok tanah air, sehingga sering menimbulkan kesenjangan antara kebutuhan biaya riil dan biaya yang dibayarkan sesuai struktur pembiayaan INA-DRG. Ditambah lagi dengan perbedaan struktur tarif untuk tindakan yang sama pada rumah sakit dengan kelas yang berbeda membuat sistem pembiayaan INA-DRG masih perlu mendapatkan kajian yang lebih baik. Ada beberapa tujuan dari sistem pembiayaan prospektif. Pertama, mengendalikan biaya kesehatan. Kedua, mendorong pelayanan kesehatan tetap bermutu sesuai dengan standar. Ketiga, membatasi pelayanan kesehatan yang tidak diperlukan. Keempat, mempermudah administrasi klaim. Kelima, mendorong Grouper untuk melakukan kendali biaya (cost containment).

Manfaat DRG adalah menyederhanakan sistem dan beban administrasi pihak penanggung dan penyedia pelayanan kesehatan, perhitungan biaya pelayanan tidak lagi secara rinci, pelayanan menjadi lebih efektif dan efisien karena mampu mengendalikan biaya pelayanan kesehatan. DRG dapat memberikan kepastian biaya rumah sakit dan meningkatkan mutu pelayanan rumah sakit. DRG dapat mengurangi biaya rumah sakit, intensitas pelayanan yang diberikan, lama hari rawat dan dapat menghasilkan produk yang lebih efisien.

Dalam penelitian Haninditya et al., (2019) didapatkan hubungan kepatuhan pelaksanaan clinical pathway terhadap total biaya riil pasien sectio caesarea dengan nilai ( $\mathrm{p}=0,000)$. Penelitian Bai et al., (2018) mengatakan dari lima kasus menunjukkan bahwa kepatuhan clinical pathway mampu mengurangi LOS (Length of Stay) dan biaya rawat inap dengan kasus sectio caesarea memiliki hubungan dengan nilai $\mathrm{p}<0,001$.

Peraturan Presiden Nomor 12 tahun 2013 tentang Jaminan Kesehatan pasal 39 ayat (3) BPJS Kesehatan melakukan pembayaran kepada fasilitas kesehatan rujukan tingkat lanjutan berdasarkan Indonesian Case Based Groups (INA-CBG's) dan ayat (4) Besaran kapitasi dan Indonesian Case Based Groups (INA-CBG's) ditinjau sekurang-kurangnya setiap 2 (dua) tahun sekali oleh menteri setelah berkoordinasi dengan menteri yang menyelenggarakan urusan pemerintahan di bidang keuangan. Dengan adanya peraturan ini, maka rumah sakit dituntut untuk tidak hanya menyelenggarakan pelayanan kesehatan yang bermutu tetapi juga harus efisien menuntut rumah sakit untuk membuat instrumen pengendali mutu pelayanan dan sekaligus pengendali biaya pelayanan, sehingga peran Pedoman Praktek Klinik (PPK) dan clinical pathway sebagai pelengkapnya menjadi sangat penting. 
Perbedaan yang paling mendasar antara tarif yang berlaku di RSUD Dr. Soetomo dengan tarif INA-CBG adalah cara perhitungan tarif tersebut. Tarif yang sampai saat ini berlaku di RSUD Dr. Soetomo merupakan tarif yang dihitung dengan cara Fee For Service, sedangkan pola tarif INA-CBG menggunakan Prospective Payment. Sehingga memberikan dampak selisih yang lebih besar antara total biaya riil BPJS yang mengalami tindakan sectio caesarea daripada pendapatan paket INA-CBG sebesar Rp 3.688.373,- kemungkinan dapat disebabkan oleh tidak efisiennya pelayanan yang diberikan, meskipun Panduan Praktek Klinik (PPK) tindakan sectio caesarea sudah ada, tetapi pada PPK tersebut tidak diatur secara rinci langkah-langkah layanan yang diberikan sehingga dibutuhkan clinical pathway, menyediakan secara rinci setiap tahap penting dari pelayanan kesehatan.

Survey nasional yang dilakukan oleh (Manser, Frings, Heuser, \& Dermott, 2016) sebanyak 527 RS dan pusat rehabilitasi berpartisipasi terkait implementasi risk management didapatkan Sebagian besar rumah sakit ini sudah memiliki strategi CRM formal termasuk didalamnya clinical pathway sebanyak (72\%), (66\%) terpusat dan (34\%) terdesentralisasi.

Clinical pathway (CP) adalah suatu konsep perencanaan pelayanan terpadu yang merangkum setiap langkah yang diberikan kepada pasien berdasarkan standar pelayanan medis dan asuhan keperawatan yang berbasis bukti dengan hasil yang terukur dan dalam jangka waktu tertentu selama di rumah sakit. Clinical pathway adalah catatan tahapan pelayanan klinis untuk sekelompok pasien dengan diagnosis tertentu. Clinical pathway dapat dibuat spesifik sesuai dengan ketentuan institusi yang menggunakannya, biasanya terdiri dari 4 hal yaitu waktu pelaksanaan, kategori perawatan atau kegiatan dan intervensinya, kriteria outcome dan catatan mengenai varians. Efektivitas clinical pathway baru dapat diperoleh bila pathway disusun dengan mengikutsertakan berbagai pihak yang terlibat dalam pemberian layanan tersebut, sehingga semua pihak yang terlibat mau memakai clinical pathway dengan benar. Bila tidak, maka clinical pathway tersebut tidak menjadi bagian dalam pelayanan klinis sehari-hari dan pathway tersebut hanya menjadi beban tambahan dalam proses pelayanan.

Penelitian ini bertujuan melakukan kajian terhdap penerapan clinical pathway sebagai instrumen pengendalian biaya pelayanan di RSUD Dr. Soetomo dengan tinjauan kasus pada pasien BPJS yang mendapatkan tindakan sectio caesarea dengan sistem pembayaran INA-DRG/CBG.

\section{METODE PENELITIAN}

\section{Desain Penelitian, Populasi dan Sampel}

Metode yang digunakan dalam penelitian ini adalah action research, dimana suatu siklus penelitian yang bertujuan utnuk memecahkan suatu masalah tertentu menggunakan kaidah penelitian guna menghasilkan pedoman yang lebih baik. Populasi penelitian ini adalah dokumen rekam medis semua pasien melahirkan yang menjalani persalinan di RSUD Dr. Soetomo pada tahun 2014. Sampel penelitian sebanyak 126 pasien BPJS yang dilakukan tindakan sectio caesarea dengan dokumen rekam medis dan lembar clinical pathway. Penelitian ini dilakukan pada tanggal 1 Januari s.d. 31 Maret 2014. Variabel bebas dalam penelitian ini adalah clinical pathway, Variabel tergantung pada penelitian ini adalah biaya riil dan biaya tertagih sesuai pola pembiayaan INA-CBG.

\section{Instrumen Penelitian}

Instrumen dalam penelitian ini menggunakan Implementasi clinical pathway dan focus group discussion. 


\section{Prosedur Penelitian dan Analisis Data}

Data penelitian akan dicatat dalam formulir pengumpulan data yang dirancang khusus untuk penelitian ini. Setelah dilakukan inventarisasi data kemudian data dikelompokkan sesuai dengan capaian pengisian form clinical pathway menjadi kelompok pengisian clinical pathway lengkap dan kelompok pengisian clinical pathway tidak lengkap. Dari semua data yang terkumpul dilakukan uji statistik One Way Anova dengan pertimbangan bahwa populasi yang akan diuji terdistribusi normal, varian dari populasi tersebut sama dan sampel tidak berhubungan satu sama lain. Tingkat kemaknaan yang digunakan $95 \%$ atau $\mathrm{p}=0.05$. Penghitungan statistik menggunakan alat bantu perangkat lunak SPSS.

\section{HASIL PENELITIAN}

Tabel. 1

Perbandingan Biaya Riil Tindakan Sectio caesarea

Sebelum dan Sesudah Implementasi Clinical pathway

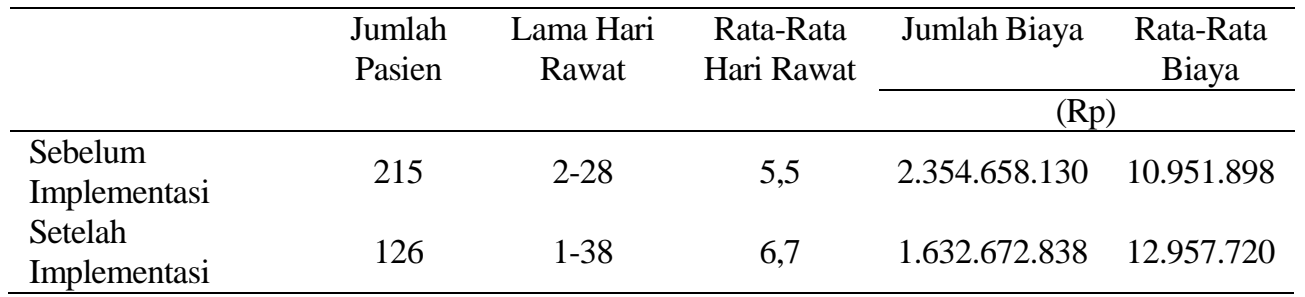

Berdasarkan tabel 1 menunjukkan bahwa setelah dilakukan implementasi clinical pathway didapatkan 196 pasien yang menjalani tindakan sectio caesarea, 126 pasien peserta BPJS Kesehatan dan 75 pasien non-BPJS Kesehatan. Dari 126 pasien peserta BPJS Kesehatan hanya 65 kasus yang clinical pathway nya diisi cukup lengkap dan dapat dievaluasi, sedangkan 61 kasus tidak lengkap sehingga tidak bisa dievaluasi.

Tabel. 2

Perbandingan Rata-Rata Hari Rawat dan Biaya Riil Pasien BPJS Kesehatan dengan Clinical pathway Lengkap dan Clinical pathway Tidak Lengkap $(\mathrm{n}=126)$

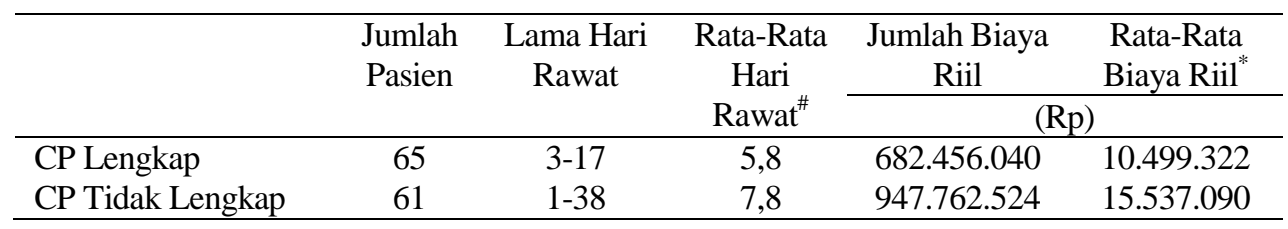

Berdasarkan tabel 2 menunjukkan bahwa perbandingan biaya antara biaya yang dikeluarkan rumah sakit sebelum implementasi clinical pathway dengan biaya yang dikeluarkan oleh rumah sakit setelah implementasi clinical pathway pada tindakan sectio caesarea pada menunjukkan bahwa rata-rata biaya tindakan sectio caesarea pasca implentasi clinical pathway lebih tinggi daripada sebelum implementasi dan dengan uji t maka perbedaan tersebut bermakna dengan $p=0,019$. Akan tetapi bila memperhatikan pada rata-rata hari rawat yang lebih lama pada pasca implementasi clinical pathway maka selisih tersebut kemungkinan menunjukkan tingkat keparahan penyakit yang lebih tinggi pada kelompok pasca implementasi. 
Tabel. 3

Perbandingan Rata-Rata Biaya Pelayanan, Biaya Obat, Biaya Riil dan Biaya Tertagih Antara Kasus BPJS Kesehatan dengan Clinical pathway Lengkap dan Tidak Lengkap $(\mathrm{n}=126)$

\begin{tabular}{lcccc}
\hline & $\begin{array}{c}\text { Biaya } \\
\text { Pelayanan }\end{array}$ & Biaya Obat & Biaya Riil & $\begin{array}{c}\text { Biaya Tertagih } \\
\text { INA-CBG }\end{array}$ \\
\cline { 2 - 5 } & \multicolumn{3}{c}{$(\mathrm{Rp})$} \\
\hline CP Lengkap & 9.650 .180 & 1.810 .393 & 10.499 .324 & 6.307 .265 \\
CP Tidak Lengkap & 13.560 .408 & 2.851 .130 & 15.537 .091 & 8.171 .223 \\
& $\mathrm{p}=0,013$ & $\mathrm{p}=0,073$ & $\mathrm{p}=0,012$ & $\mathrm{p}=0,122$ \\
\hline
\end{tabular}

Berdasarkan tabel 3 perbandingan antara lama hari rawat dengan biaya riil pada kasus dengan clinical pathway lengkap dan clinical pathway tidak lengkap menunjukkan bahwa kasus dengan clinical pathway lengkap mempunyai hari rawat yang lebih pendek secara bermakna $(p=0,037)$ dan rata-rata biaya riil yang lebih rendah secara bermakna $(p=0,012)$ dibandingkan kasus dengan clinical pathway tidak lengkap. Sehingga clinical pathway dapat dipakai untuk memberikan pelayanan yang tepat waktu dan standar, serta mengurangi variasi pelayanan yang tidak perlu sehingga pelayanan menjadi lebih efisien dan biaya pelayanan dapat dikendalikan.

Perbandingan rata-rata biaya pelayanan, biaya obat, biaya riil dan biaya tertagih antara kasus BPJS Kesehatan dengan clinical pathway lengkap dan tidak lengkap di dalam [Table 4] terdapat perbedaan bermakna biaya pelayanan $(\mathrm{p}=0,013)$ dan biaya riil $(\mathrm{p}=$ 0,012) antara kasus JKN dengan clinical pathway lengkap dan clinical pathway tidak lengkap.

\section{PEMBAHASAN}

Pada waktu implementasi tiga bulan tersebut, terdapat 196 kasus tindakan sectio caesarea, dimana 126 kasus diantaranya merupakan peserta BPJS Kesehatan hanya 65 (51.58\%) kasus yang pengisian clinical pathway nya cukup lengkap dan bisa di evaluasi, sedangkan sebanyak $61(48.42 \%)$ kasus tidak diisi dengan lengkap. Keadaan ini kemungkinan disebabkan karena posisi clinical pathway yang belum jelas dalam dokumen rekam medis pasien.

Rata-rata biaya riil pasca implementasi clinical pathway justru lebih tinggi secara bermakna dibandingkan sebelum implementasi. Tingginya biaya riil ini kemungkinan disebabkan karena peningkatan jumlah pasien rujukan dengan tingkat keparahan yang lebih tinggi dimana kasus dengan severity level 1 menurun dari 87,90\% sebelum implementasi clinical pathway menjadi $74,60 \%$ pasca implementasi. Sementara itu, jumlah pasien rujukan dengan severity level 3 meningkat dari 2,79\% sebelum implementasi clinical pathway menjadi 12,69\% pasca implementasi, sedangkan severity level 2 hampir tidak ada perubahan. Keadaan ini merupakan dampak langsung dari posisi RSUD Dr. Soetomo sebagai PPK-3, yang seharusnya hanya memberikan pelayanan spesialistik dan subspesialistik Keadaan tersebut ditambah lagi dengan mulai diberlakukannya jejaring pelayanan rujukan di Jawa Timur sehingga RSUD Dr. Soetomo seharusnya hanya menerima rujukan dari rumah sakit kelas B yang menerima rujukan dari rumah sakit kelas $\mathrm{C}$ dan D di kabupaten/kotamadya.

Pada penelitian ini dilakukan perbandingan antara pasien BPJS Kesehatan yang menjalani tindakan sectio caesarea dan clinical pathway terisi lengkap dengan pasien yang clinical pathway tidak terisi atau terisi tetapi tidak lengkap. Hasil penelitian ini didapatkan bahwa kasus dengan clinical pathway lengkap mempunyai rata-rata hari rawat yang lebih pendek secara bermakna dibandingkan dengan yang clinical pathway tidak diisi atau tidak 
lengkap. Selain itu rata-rata biaya riil juga lebih rendah secara bermakna pada kasus dengan clinical pathway yang lengkap.

Penelitian Bai et al., (2018) mengatakan dari lima kasus menunjukkan bahwa kepatuhan clinical pathway mampu mengurangi LOS (Length of Stay) dan biaya rawat inap dengan kasus sectio caesarea memiliki hubungan dengan nilai $\mathrm{p}<0,001$.

Selanjutnya dibandingkan biaya pelayanan, biaya obat, biaya riil dan biaya tertagih antara kasus BPJS Kesehatan yang lengkap clinical pathway nya dengan yang tidak lengkap clinical pathway nya. Didapatkan bahwa pada kasus dengan clinical pathway tidak lengkap lebih tinggi secara bermakna untuk biaya pelayanan dan biaya riil. Sekali lagi hal ini menunjukkan bahwa implementasi clinical pathway dapat menurunkan biaya riil yang dibutuhkan dalam memberikan pelayanan tindakan sectio caesarea. Penelitian yang dilakukan Haninditya et al., (2019) didapatkan hubungan kepatuhan pelaksanaan clinical pathway terhadap total biaya riil pasien sectio caesarea dengan nilai $(\mathrm{p}=0,000)$.

Manfaat yang diharapkan dari clinical pathway $s$ selain adanya peningkatan mutu pelayanan yang standar berdasarkan studi kedokteran berbasis bukti, adalah efektivitas biaya. Pada era Jaminan Kesehatan Nasional yang menggunakan sistem DRG-Casemix (dengan kode penyakit berdasarkan ICD 10 dan ICD 9-CM dan prosedur tindakan dan biaya), clinical pathway dapat digunakan sebagai salah satu alat untuk melakukan audit medis yang tujuannya berujung pada peningkatan mutu pelayanan. Pemberian vitamin $\mathrm{K}$ pada bayi yang baru saja lahir merupakan contoh bahwa clinical pathway dapat berdampak pada adanya revisi Standar Pelayanan Medis (SPM) atau Standar Prosedur Operasional (SPO) (Komisi Akreditasi Rumah Sakit, 2017).

Penelitian Astuti et al., (2017) menjelaskan formulir clinical pathway sectio caesarea yang dinilai adalah benar sebuah clinical pathway menurut standar penilaian ICPAT dan pada bagian konten dan mutu termasuk dalam kriteria moderate. Peran organisasi rumah sakit pada aspek konten masuk dalam kriteria baik, sedangkan aspek mutu termasuk dalam kriteria moderate. Kebutuhan tenaga perawat dan dokter sudah sesuai dengan kebutuhan tenaga yang diperlukan dan sudah sesuai standar yang ada. Namun tenaga non keperawatan masih kurang dari jumlah kebutuhan. Pada aspek sarana dan prasarana terdapat kekurangan alat medis dalam hal kuantitas yang masih belum sesuai dengan standar yang diperlukan.

Evaluasi pelaksanaan clinical pathway di rumah sakit didapatkan sebagian besar rumah sakit telah mempunyai standar clinical pathway tetapi belum berperan aktif secara optimal dalam kendali mutu dan kendali biaya (Rezkiki et al., 2018). Sejalan dengan itu Penelitan oleh Mutawalli (2018) mengatakan penerapan clinical pathway tidak terrealisasi sempurna karena kendala seperti; kekurangan sumber daya peralatan, fasilitas kesehatan, kelalaian pelaksana teknis; dokter, perawat, gizi dan farmasi

Beberapa faktor yang memperngaruhi keberhasilan pengembangan dan pelaksanaan clinical pathway di Rumah Sakit yaitu, memiliki manajemen budaya risiko klinis ditetapkan di rumah sakit, memiliki pendanaan yang cukup untuk menunjuk seorang perawat senior untuk mengkoordinasikan program ini, untuk membayar staf yang ikut serta dalam tim untuk pekerjaan tambahan, dan untuk membayar staf pengganti untuk melaksanakan tugas rutin, melibatkan tim multidisiplin dalam pengembangan clinical pathway, sehingga meningkatkan komunikasi dan kerja sama tim antara profesional kesehatan dari disiplin ilmu yang berbeda serta memberikan kepemilikan (ownership) atas masing-masing clinical pathway kepada semua staf yang memberikan pelayanan, melakukan pencarian literatur untuk menentukan praktek klinis terbaik untuk setiap kondisi medis dan mengadaptasi berdasarkan evidence base untuk kondisi lokal sebelum memasukkan ke dalam clinical pathway. 
Merinci proses perawatan di setiap clinical pathway dalam bentuk daftar periksa (checklist) dan pengingat (reminder), keterlibatan staf medis sebagai kunci awal dalam proses pengembangan clinical pathway dan menghadirkan seluruh staf medis untuk mengomentari individual pathways sebelum pelaksanaannya dilakukan, memasukkan clinical pathway ke dalam rekam medis pasien dan memastikan bahwa seluruh staf klinis telah selesai memberikan perawatan, dan memberikan feedback berkala tentang hasil program clinical pathway untuk seluruh staf klinis, kelompok klinis dan komite rumah sakit yang sesuai (Astuti et al., 2017).

\section{SIMPULAN}

Clinical pathway diisi dengan lengkap dan benar serta pengisian clinical pathway terbukti mengurangi lama hari rawat dan biaya riil pada kasus BPJS Kesehatan yang menjalani tindakan sectio caesarea.

\section{SARAN}

Diharapkan rumah sakit dapat menerapkan nursing clinical pathway dalam pengendalian biaya BPJS pada pasien dirawat inap serta membuat suatu kebijakan terkait dengan pelaksanaan nursing clinical pathway.

\section{DAFTAR PUSTAKA}

Astuti, D. Y., Dewi, A., \& Arini, M. (2017). Evaluasi Implementasi Clinical pathway Sectio Caesarea di RSUD Panembahan Senopati Bantul. Jurnal Medicoeticolegal dan Manajemen Rumah Sakit, 6(2). https://doi.org/10.18196/jmmr.6133

Bai, J., Bai, F., Zhu, H., \& Xue, D. (2018). The Perceived and Objectively Measured Effects of Clinical pathway s' Implementation on Medical Care in China. PLoS ONE, 13(5), e0196776. https://doi.org/10.1371/journal.pone.0196776

Haninditya, B., Andayani, T. M., \& Yasin, N. M. (2019). Analysis of Cesarean Section Clinical pathway Compliance at a Private Hospital in Yogyakarta. Jurnal Manajemen Dan Pelayanan Farmasi (Journal of Management and Pharmacy Practice), 9(1), 38. https://doi.org/10.22146/jmpf.42264

Komisi Akreditasi Rumah Sakit. (2017). Standar Nasional Akreditasi Rumah Sakit (1st.ed). Komisi Akreditasi Rumah Sakit. http://web90.opencloud.dssdi.ugm.ac.id/wpcontent/uploads/sites/644/2018/05/Sna rs-Edisi-1.pdf

Mutawalli, L. (2018). Sistem Audit Clinical pathway di Rumah Sakit Islam Harapan Anda Kota Tegal. Universitas Islam Indonesia

Rezkiki, F., Dharma, S., \& Yasmi, Y. (2018). Pengaruh Penerapan Nursing Clinical Pathway terhadap Lama Hari Rawat Pasien Stroke Non Hemoragik. Jurnal Ipteks Terapan, 12(1), 9-18. https://doi.org/https://doi.org/10.22216/jit.2018.v12i1.1158 